\title{
EFFECT OF SOMATIC CELL COUNT ON MILK FAT AND PROTEIN IN DIFFERENT PARITIES AND STAGES OF LACTATION IN HOLSTEIN COWS
}

\author{
Arash CHEGINI ${ }^{1,2}$, Navid GHAVI HOSSEIN-ZADEH ${ }^{1}$, Hossein HOSSEINI-MOGHADAM ${ }^{1}$, \\ Abdol Ahad SHADPARVAR ${ }^{1}$
}

Received March 4, 2017; accepted December 14, 2017.

Delo je prispelo 4. marca 2017, sprejeto 14. decembra 2017.

\begin{abstract}
Effect of somatic cell count on milk fat and protein in different parities and stages of lactation in Holstein cows

The objective of this study was to investigate the effect of somatic cell score (SCS) on milk fat and protein in different parities and stages of lactation in Iranian Holstein cows. Records between June 2003 and January 2014 from 208,478 cows in lactations one to nine in 845 herds, comprising 2,456,303 monthly test-day (TD) records were used. The MIXED procedure of the SAS software with repeated measurements was used. The fixed effects of the model were herd, year-season of calving, month of TD, weeks of lactation, previous dry period length and somatic cell score (SCS) and covariate was calving age. Lactations were divided into six stages and analyses were performed within each stage. Also, different lactations were analyzed separately. Increase of SCS led to increase of milk fat and protein percentage and the increase of milk fat and protein associated with SCS was higher in early stages of lactation relative to later stages of lactation. Also, increase of milk fat and protein associated with SCS was higher in the first lactation rather than later lactations and decreased with increase of parity.

Key words: cattle; dairy cows; breeds; Holstein; milk; proteins; fat; somatic cell score; lactation; Iran
\end{abstract}

\section{INTRODUCTION}

In addition to the quantity of milk, the quality of milk has received much attention in the recent years. Milk composition and its microbial properties are important for farmers (in terms of raw milk quality) and consumers (in terms of curing process and quality of products). Factors affecting milk composition include breed, age, udder health condition, stage of lactation, feeding management
Vpliv števila somatskih celic na odstotek maščobe in beljakovin $v$ mleku holštajnskih krav $v$ različnih zaporednih laktacijah in $v$ različnih stadijih laktacije

Namen te raziskave je bil proučiti učinek števila somatskih celic (SCS) na vsebnost mlečne maščobe in beljakovin v različnih laktacijah in v različnih fazah laktacije pri iranskih kravah holštajnske pasme. Uporablili smo podatke za $208.478 \mathrm{krav} \mathrm{v}$ prvi do deveti laktaciji iz 845 čred, ki so vsebovali 2.456 .303 zapisov za mesečni testni dan (TD). Analiza je bila opravljena s proceduro MIXED s ponovljenimi meritvami v programskem paketu SAS. Fiksni vplivi v modelu so bili čreda, leto-sezona telitve, mesec testnega dneva, teden laktacije, trajanje predhodne presušitve in število somatskih celic ter starost ob telitvi kot kovariabla. Laktacije smo razdelili v šest obdobij in opravili analize znotraj vsakega obdobja. Analize so bile opravljene ločeno po laktacijah. Povečanje števila somatskih celic je vodilo do povečanja odstotka maščob in beljakovin, ki je bilo večje v zgodnjih obdobjih laktacije v primerjavi s kasnejšimi. Povečanje vsebnosti maščob in beljakovin je bilo tudi večje v prvi laktaciji kot $\mathrm{v}$ kasnejših laktacijah in je upadalo $\mathrm{z}$ zaporedno laktacijo.

Ključne besede: govedo; krave; molznice; pasme; holštajn; mleko; beljakovine; maščobe; število somatskih celic; laktacija; Iran

and season (Dobranié et al., 2008). Feeding management and change in feed compositions lead to change in milk fat and protein content. Also, the amount of dry matter intake, dietary fiber and energy to protein ratio are considered as the major factors influencing milk fat and protein content (Allen, 2000).

Mastitis is one of the most common diseases in dairy cows and causes huge economic losses in this industry (Halasa et al., 2007). Mastitis is defined as inflammation

1 University of Guilan, Faculty of Agricultural Sciences, Department of Animal Science, Rasht, Iran

2 Corresponding author, e-mail: cheginiarash@yahoo.com 
of mammary gland and occurs as a result of entry and proliferation of pathogenic microorganisms in the udder (Harmon, 1994). Effect on the cow's defense mechanism, multiplication in the udder and toxin production (that is harmful to the mammary gland) is the consequence of entrance of pathogenic microorganisms into the udder through the teat canal. Mammary tissue is then damaged, which causes increased vascular permeability. As a result of this, milk composition is altered; there is leakage of blood constituents, serum proteins, enzymes, and salts into the milk and decreased synthesis of caseins and lactose and decreased fat quality (Harmon, 1994; Østerås, 2000). The extent of these changes is determined by the severity of the infection (Harmon, 1994; Pyörälä, 2003).

Control mammary infections in dairy cows is essential in order to maintain milk quality. There are many ways to detect intra-mammary infection and cultivation of microorganisms from milk samples is considered as a standard method (Dohoo et al., 2011). But since it's a costly and time-consuming method is not suitable for routine diagnosis. At present, the number of somatic cells is used to check the udder health status at the herd and animal level (Schukken et al., 2003), because it can be obtained from routine milk recording at no extra cost compared to microbial culture.

Accurate estimates of changes in milk composition due to increase in the number of somatic cells can be an incentive for breeders to consider the effects of such disorders in selection index by allocating appropriate economic weights. Estimates of change in milk compositions are rare and are not suitable for economic calculations (Seegers et al., 2003). To our knowledge, effect of somatic cell count on milk fat and protein content in different parities and stages of lactation has not been investigated yet. Therefore, the aim of this study is to investigate the effect of somatic cell count on milk fat and protein content in different parities and stages of lactation in the Iranian Holstein cows.

\section{MATERIAL AND METHODS}

A total of 2,456,303 test-day records of 208,478 animals were used in lactations one to nine collected from 845 herds from June 2003 to January 2014. Dataset included: animal number, calving dates, parity, age at calving, milk fat and protein percentage, somatic cell count, test dates and drying off dates. Test-day records from 5 to 305 days in milk were included in the analyses. Also, animals should have at least five test-day records to be included in the analyses. Somatic cell counts have a lognormal distribution and were transformed to somatic cells score as: class 0: 0-17,000 (cell/ml), class 1: 18,000-
Table 1: Number (percent) of data in different SCS's classes and lactations

\begin{tabular}{llcc}
\hline SCS & $1^{\text {st }}$ lactation & $2^{\text {nd }}$ lactation & $\geq 3^{\text {rd }}$ lactation \\
\hline 0 & $121,881(13.74)$ & $54,111(9.12)$ & $57,333(5.88)$ \\
1 & $236,494(26.65)$ & $101,544(17.11)$ & $116,246(11.92)$ \\
2 & $200,721(22.62)$ & $119,401(20.12)$ & $154,436(15.83)$ \\
3 & $126,273(14.23)$ & $105,030(17.70)$ & $162,917(16.70)$ \\
4 & $83,375(9.40)$ & $84,920(14.31)$ & $159,026(16.30)$ \\
5 & $51,973(5.86)$ & $57,992(9.77)$ & $131,623(13.49)$ \\
6 & $33,242(3.75)$ & $36,316(6.12)$ & $95,624(9.80)$ \\
7 & $19,102(2.15)$ & $20,234(3.41)$ & $57,361(5.88)$ \\
8 & $9,644(1.08)$ & $9,753(1.65)$ & $28,427(2.91)$ \\
9 & $4,657(0.52)$ & $4,083(0.69)$ & $12,564(1.29)$ \\
\hline
\end{tabular}

${ }^{*} 0: 0-17,000$ (cell/ml), 1: 18,000-34,000, 2: 35,000-70,000, 3: 71,000$140,000,4: 141,000-282,000,5: 283,000-565,000,6: 566,000-1,130,000$, 7: 1,131,000-2,262,000, 8: 2,263,000-4,525,000, 9: 4,526,000-and above.

34,000, class 2: $35,000-70,000$, class 3: 71,000-140,000, class 4: $141,000-282,000$, class 5: $283,000-565,000$, class 6: 566,000-1,130,000, class 7: 1,131,000-2,262,000, class 8: 2,263,000-4,525,000, class 9: 4,526,000-and above. Number (percent) of data in different SCS's classes and lactations is shown in Table 1. Calving months were grouped into four seasons (spring: April through June; summer: July through September; fall: October through December and winter: January through March). According to a study by Hagnestam-Nielsen et al. (2009) each lactation was divided into six stages (weeks $1-2$, weeks $3-8$, weeks 9-16, weeks $17-24$, weeks $25-32$ and weeks 33-44) and analyses were performed within each stage. Also, dry period length of cows was grouped into 14 classes: $0-10$ days (class 1), 11-20 days (class 2), 21-30 days (class 3 ), 31-40 days (class 4 ), $41-50$ days (class 5 ), 51-60 days (class 6), 61-70 days (class 7), 71-80 days (class 8 ), 81-90 days (class 9), 91-100 days (class 10), 101-110 days (class 11), 111-120 days (class 12), 121-130 days (class 13) and $>130$ days (class 14). Weeks in lactation were divided into 19 classes (records of first 8 weeks of lactation were grouped into weekly intervals, records from week 9 to 16 were grouped into 2 -week periods, and records collected from week 17 to 44 were grouped into 4-week periods). A summary of descriptive statistics of phenotypic values for daily milk yield, fat and protein percentage, somatic cell count (SCC), SCS, calving age and previous dry period length is shown in Table 2. The MIXED procedure of SAS software (SAS Institute Inc., 2002) with repeated measurements was used to investigate the effect of SCS on milk fat and protein percentage in different stages of lactation with the following model: 
Table 2: Summary of descriptive statistics of phenotypic values

\begin{tabular}{|c|c|c|c|c|c|c|c|c|}
\hline & Trait & Avg & Min & Max & SD & Mode & Median & $\mathrm{CV}(\%)$ \\
\hline \multirow{6}{*}{ 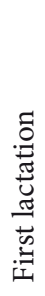 } & Milk (kg) & 32.94 & 8 & 76 & 7.36 & 33 & 33 & 22.34 \\
\hline & Fat (\%) & 3.236 & 0.01 & 9.9 & 0.87 & 3 & 3.22 & 26.88 \\
\hline & Protein (\%) & 3.088 & 0.01 & 9.9 & 0.42 & 3 & 3.08 & 13.60 \\
\hline & $\operatorname{SCC}^{*(1000)}$ & 211.7 & 10 & 20000 & 695.7 & 21 & 45 & 328.62 \\
\hline & SCS & 2.324 & 0 & 9 & 1.882 & 1 & 2 & 80.98 \\
\hline & Calving age (mo) & 25.71 & 18 & 40 & 3.933 & 24.33 & 24.8 & 15.30 \\
\hline \multirow{7}{*}{ 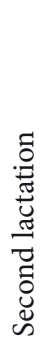 } & Milk (kg) & 36.08 & 8 & 85 & 9.99 & 36 & 36.2 & 27.69 \\
\hline & Fat $(\%)$ & 3.321 & 0.01 & 9.9 & 0.927 & 2.5 & 3.3 & 27.91 \\
\hline & Protein (\%) & 3.135 & 0.01 & 9.72 & 0.410 & 3 & 3.11 & 13.08 \\
\hline & $\operatorname{SCC}^{*(1000)}$ & 302.8 & 10 & 19957 & 787.1 & 21 & 80 & 259.9 \\
\hline & SCS & 2.965 & 0 & 9 & 1.998 & 2 & 3 & 67.39 \\
\hline & Calving age (mo) & 39.65 & 28.2 & 60 & 4.783 & 36.47 & 38.53 & 12.06 \\
\hline & $\mathrm{PDPL}^{*}$ (day) & 81.53 & 0 & 250 & 68.36 & 60 & 63 & 83.85 \\
\hline \multirow{7}{*}{ 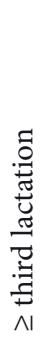 } & Milk (kg) & 35.85 & 8 & 90 & 10.89 & 36 & 36 & 30.38 \\
\hline & Fat (\%) & 3.356 & 0.01 & 9.9 & 0.954 & 2.5 & 3.31 & 28.43 \\
\hline & Protein (\%) & 3.103 & 0.01 & 9.7 & 0.408 & 3 & 3.08 & 13.15 \\
\hline & $\operatorname{SCC}^{*(1000)}$ & 467.9 & 10 & 19994 & 1023 & 21 & 139 & 218.64 \\
\hline & SCS & 3.612 & 0 & 9 & 2.123 & 3 & 3 & 58.78 \\
\hline & Calving age (mo) & 68.00 & 37.9 & 176 & 18.49 & 50.1 & 63.37 & 27.19 \\
\hline & $\mathrm{PDPL}^{*}$ (day) & 77.70 & 0 & 250 & 41.89 & 60 & 65 & 53.91 \\
\hline
\end{tabular}

* Previous dry period length (there was no PDPL for first lactation cows).

TD milk fat or protein $\%=$ animal number + herd + yearseason of calving + month of TD + calving age + weeks in lactation + previous dry period length + SCS + random residual.

Fixed effects were: herd, year-season of calving, month of TD, weeks in lactation, previous dry period length and SCS, and covariate was calving age. Different lactations were analyzed separately. Animal registration number was considered as subject and autoregressive type was used. Also, REG procedure was used to quantify amount of change in milk fat and protein percentage per each increase in SCS within each stage. Also, test-dates were grouped into four seasons (as mentioned for calving months in above) and the season effect of test-day was investigated on content and percentage of milk fat and protein.

\section{RESULTS AND DISCUSSION}

Average of milk fat and protein percentage in first, second and third and following lactations were 3.236, 3.321 and 3.356 (for fat), and 3.088, 3.135 and 3.103 (for protein), respectively. Also, mean of SCS in first, second and third and following lactations were 2.324, 2.965 and 3.612 , respectively. Table 1 shows the number of records in different SCS's classes in different lactations. Previous studies showed that the lactation number has a significant effect on somatic cell count and milk of multiparous cows has higher number of somatic cells (Olde Riekerink et al., 2007; Chegini, 2010; Ghasemi et al., 2013). Ghasemi et al. (2013) showed that higher parity cows had higher production, and considering the negative correlation between milk yield and mastitis, higher parity cows were in higher risk of mastitis, therefore, they had higher somatic cell count. However, regarding the decreasing trend of average milk yield of cows in lactation $\geq 5$, it was expected these cows to have lower somatic cell count. It can be concluded that some physical changes occur with increasing age of the animal including weaker teat sphincters, deeper udder that is in more exposure to the environmental pathogens and also immune system of an old cow respond faster and more severe to pathogens that leads to higher number of somatic cells. Ohtsuka et al. (2010) found that despite of lower cellular immune function, multiparous cows had significantly higher mammary gland immune cells at calving.

Variation in milk fat and protein percentage in dif- 
Table 3: Milk fat and protein percentage in different SCS's classes and stages of lactation in comparison with SCS zero in the first lactation (120,149 animals with 887,362 records from 759 herds with 43 levels for YS of calving)

\begin{tabular}{|c|c|c|c|c|c|c|c|}
\hline \multirow[b]{3}{*}{$\operatorname{SCS}^{*}$} & \multicolumn{7}{|c|}{ Week in lactation } \\
\hline & 1 & 2 & $3-8$ & $9-16$ & $17-24$ & $25-32$ & $33-44$ \\
\hline & \multicolumn{7}{|c|}{ Fat percentage } \\
\hline 0 & --- & --- & --- & --- & --- & --- & --- \\
\hline 1 & $0.222^{\mathrm{a}}$ & 0.235 & 0.185 & 0.154 & 0.121 & 0.118 & 0.123 \\
\hline 2 & 0.482 & 0.413 & 0.319 & 0.228 & 0.189 & 0.183 & 0.193 \\
\hline 3 & 0.592 & 0.533 & 0.386 & 0.262 & 0.218 & 0.203 & 0.236 \\
\hline 4 & 0.650 & 0.525 & 0.392 & 0.304 & 0.247 & 0.223 & 0.262 \\
\hline 5 & 0.601 & 0.559 & 0.429 & 0.330 & 0.275 & 0.241 & 0.270 \\
\hline 6 & 0.612 & 0.589 & 0.465 & 0.336 & 0.294 & 0.269 & 0.295 \\
\hline 7 & 0.804 & 0.634 & 0.485 & 0.403 & 0.367 & 0.315 & 0.331 \\
\hline 8 & 1.004 & 0.694 & 0.610 & 0.486 & 0.426 & 0.390 & 0.378 \\
\hline 9 & 0.746 & 0.843 & 0.853 & 0.694 & 0.619 & 0.598 & 0.538 \\
\hline $\mathrm{SCS}^{*}$ & \multicolumn{7}{|c|}{ Protein percentage } \\
\hline 0 & --- & --- & --- & --- & --- & --- & --- \\
\hline 1 & $0.009^{\text {ns }}$ & $0.021^{\mathrm{ns}}$ & $0.010^{\mathrm{a}}$ & $0.005^{\mathrm{a}}$ & 0.009 & 0.016 & 0.012 \\
\hline 2 & $0.085^{\mathrm{a}}$ & 0.079 & 0.037 & 0.020 & 0.027 & 0.036 & 0.041 \\
\hline 3 & 0.095 & 0.110 & 0.073 & 0.051 & 0.046 & 0.060 & 0.065 \\
\hline 4 & 0.105 & 0.116 & 0.108 & 0.083 & 0.073 & 0.086 & 0.090 \\
\hline 5 & 0.197 & 0.165 & 0.152 & 0.104 & 0.095 & 0.101 & 0.104 \\
\hline 6 & 0.240 & 0.181 & 0.177 & 0.132 & 0.117 & 0.123 & 0.133 \\
\hline 7 & 0.272 & 0.212 & 0.183 & 0.154 & 0.143 & 0.141 & 0.140 \\
\hline 8 & 0.283 & 0.222 & 0.233 & 0.190 & 0.168 & 0.172 & 0.182 \\
\hline 9 & 0.739 & 0.382 & 0.398 & 0.377 & 0.323 & 0.332 & 0.360 \\
\hline
\end{tabular}

${ }^{*} 0: 0-17,000$ (cell/ml), 1: 18,000-34,000, 2: 35,000-70,000, 3: 71,000-140,000, 4: 141,000-282,000, 5: 283,000-565,000, 6: 566,000-1,130,000, 7: $1,131,000-2,262,000,8: 2,263,000-4,525,000,9: 4,526,000$-and above;

All the differences were significant at $p<0.0001$; ${ }^{\mathrm{a}, \mathrm{b}}$ : significant at $p<0.01, p<0.05$; ns: non-significant

ferent SCS class and stages of lactation in comparison with SCS zero (as a basis) in first, second and third and following lactations are shown in Tables 3,4 and 5, respectively. Also, regression coefficients of fat and protein percentage on SCS in different stages of lactation, based on test-day records, in first, second and third and following lactations are shown in Table 6. Results showed that increase in SCS leads to increase in milk fat and protein percentage this increase was higher in early lactation relative to later parts of lactation. Since previous investigations (Dürr et al., 2008; Hagnestam et al., 2009) showed that increase in somatic cell count caused greater milk loss in later parts of lactation, considering the negative correlation between milk yield with fat and protein percentage, it was expected to observe higher milk fat and protein percentage in later parts of lactation with increase in SCS. Considering the protein nature of immunoglobulins and blood serum proteins, it implies that the immune system of animals respond more severe to pathogens in early lactation. Also, increase in somatic cell count leads to higher decrease in daily milk yield in higher lactations (Hortet et el. 1999; Dürr et al. 2008), however, results of present study showed lower increase in milk fat and protein percentage with increase in SCS in higher lactations relative to lower lactations. Similarly, other studies (Cunha et al., 2008; Barłowska et al., 2009; Malek dos Reis et al., 2013) reported that increase in somatic cell count was associated with increase in milk fat and protein. Bansal et al. (2005) reported that healthy quarters produce milk with lower protein percentage relative to mastitic ones $(2.96 \%$ vs. $3.22 \%$, respectively). It has been observed that milk samples collected from infected quarters contain more total protein and whey protein and less casein and lactose in comparison to healthy quarters (Kitchen, 1981; Cinar et al., 2015; Neitzel et al., 2015). During mastitis, increase in permeability of the blood-milk barrier also results in 
Table 4: Milk fat and protein percentage in different SCS's classes and stages of lactation in comparison with SCS zero in second lactation. (79,754 animals with 593,384 records from 637 herds with 43 levels for YS of calving)

\begin{tabular}{|c|c|c|c|c|c|c|c|}
\hline \multirow[b]{3}{*}{$\mathrm{SCS}^{*}$} & \multicolumn{7}{|c|}{ Week in lactation } \\
\hline & 1 & 2 & $3-8$ & $9-16$ & $17-24$ & $25-32$ & $33-44$ \\
\hline & \multicolumn{7}{|c|}{ Fat percentage } \\
\hline 0 & --- & --- & --- & --- & --- & --- & --- \\
\hline 1 & 0.315 & 0.258 & 0.127 & 0.120 & 0.125 & 0.114 & 0.122 \\
\hline 2 & 0.480 & 0.403 & 0.192 & 0.161 & 0.169 & 0.167 & 0.220 \\
\hline 3 & 0.511 & 0.430 & 0.186 & 0.181 & 0.200 & 0.200 & 0.264 \\
\hline 4 & 0.574 & 0.418 & 0.203 & 0.187 & 0.210 & 0.209 & 0.286 \\
\hline 5 & 0.555 & 0.452 & 0.238 & 0.186 & 0.218 & 0.242 & 0.306 \\
\hline 6 & 0.643 & 0.488 & 0.247 & 0.210 & 0.232 & 0.254 & 0.316 \\
\hline 7 & 0.794 & 0.491 & 0.260 & 0.265 & 0.290 & 0.279 & 0.350 \\
\hline 8 & 0.549 & 0.638 & 0.427 & 0.363 & 0.335 & 0.331 & 0.407 \\
\hline 9 & $0.573^{\mathrm{b}}$ & 0.799 & 0.659 & 0.584 & 0.594 & 0.506 & 0.569 \\
\hline $\mathrm{SCS}^{*}$ & \multicolumn{7}{|c|}{ Protein percentage } \\
\hline 0 & --- & --- & --- & --- & --- & --- & --- \\
\hline 1 & $0.103^{\mathrm{a}}$ & $0.057^{\mathrm{b}}$ & 0.014 & 0.013 & 0.017 & 0.018 & 0.028 \\
\hline 2 & 0.189 & 0.129 & 0.049 & 0.036 & 0.039 & 0.045 & 0.064 \\
\hline 3 & 0.206 & 0.148 & 0.075 & 0.060 & 0.063 & 0.066 & 0.094 \\
\hline 4 & 0.218 & 0.155 & 0.097 & 0.087 & 0.084 & 0.087 & 0.117 \\
\hline 5 & 0.233 & 0.175 & 0.125 & 0.108 & 0.107 & 0.113 & 0.140 \\
\hline 6 & 0.284 & 0.206 & 0.130 & 0.118 & 0.128 & 0.132 & 0.161 \\
\hline 7 & 0.291 & 0.254 & 0.164 & 0.140 & 0.142 & 0.147 & 0.183 \\
\hline 8 & 0.289 & 0.328 & 0.186 & 0.179 & 0.193 & 0.174 & 0.204 \\
\hline 9 & 0.537 & 0.416 & 0.338 & 0.332 & 0.313 & 0.316 & 0.358 \\
\hline
\end{tabular}

${ }^{*} 0: 0-17,000$ (cell/ml), 1: 18,000-34,000, 2: 35,000-70,000, 3: 71,000-140,000, 4: 141,000-282,000, 5: 283,000-565,000, 6: 566,000-1,130,000, 7: $1,131,000-2,262,000,8: 2,263,000-4,525,000,9: 4,526,000$-and above;

All the differences were significant at $p<0.0001$; $^{\mathrm{a}, \mathrm{b}}$ : significant at $p<0.01, p<0.05$

an influx of serum proteins and enzymes from the blood, which may lead to increased proteolysis (Forsbäck et al., 2010). Reports on aforementioned research (Bansal et al., 2005; Forsbäck et al., 2010; Malek dos Reis et al., 2013) showed change in milk composition of infected quarters (including change in level of casein, decrease in $\alpha$-casein and $\beta$-casein due to either proteolytic activity of enzymes or decreased casein synthesis in affected udder quarters, and increase in whey proteins) in comparison to milk produced by healthy quarters. Regarding to the previous reports and results of this study, it can be concluded that permeability of basal lamina is higher either in young animals or in early stages of lactation because of higher milk protein percentage and SCS in both lower lactations and early stages of lactation. However, there is inconsistency between studies about the effect of mastitis on milk fat content. Malek dos Reis et al. (2013) reported that intramammary infections caused by coagulase negative staph- ylococci, Streptococcus sp., and Corynebacterium spp. reduced milk fat content, whereas Rogers et al. (1989) reported no effect of mastitis on milk fat content. Also, Kitchen (1981) and Auldist et al. (1995) reported lower milk fat percentage for cows with subclinical mastitis, whereas Rajčevič et al. (2003) and Atasever and Stádník (2015) stated that milk samples collected from infected cows had higher milk fat and protein percentage.

Considering that regression coefficient of milk protein percentage on SCS is slightly higher than that of milk fat percentage on SCS in second and third and following lactations (Table 6), it can be concluded that large amounts of increase in milk protein associated with increase in SCS is because of adaptive immune system and protein nature of antibodies that cow achieved in first lactation. This is in agreement with reports of Ohtsuka et al. (2010), who stated that older cows are more susceptible to infection around the time of calving and have 
Table 5: Milk fat and protein percentage in different SCS's classes and stages of lactation in comparison with SCS zero in $\geq$ third lactation. (87,822 animals with 975,557 records from 649 herds with 43 levels for YS of calving)

\begin{tabular}{|c|c|c|c|c|c|c|c|}
\hline \multirow[b]{3}{*}{$\mathrm{SCS}^{*}$} & \multicolumn{7}{|c|}{ Week in lactation } \\
\hline & 1 & 2 & $3-8$ & $9-16$ & $17-24$ & $25-32$ & $33-44$ \\
\hline & \multicolumn{7}{|c|}{ Fat percentage } \\
\hline 0 & --- & --- & --- & --- & --- & --- & --- \\
\hline 1 & $0.048^{\text {ns }}$ & 0.209 & 0.130 & 0.097 & 0.110 & 0.125 & 0.141 \\
\hline 2 & 0.368 & 0.368 & 0.185 & 0.136 & 0.173 & 0.200 & 0.237 \\
\hline 3 & 0.481 & 0.379 & 0.196 & 0.145 & 0.189 & 0.237 & 0.288 \\
\hline 4 & 0.522 & 0.388 & 0.211 & 0.149 & 0.196 & 0.240 & 0.321 \\
\hline 5 & 0.461 & 0.405 & 0.212 & 0.154 & 0.198 & 0.248 & 0.323 \\
\hline 6 & 0.516 & 0.420 & 0.214 & 0.167 & 0.198 & 0.256 & 0.332 \\
\hline 7 & 0.514 & 0.412 & 0.262 & 0.204 & 0.230 & 0.292 & 0.340 \\
\hline 8 & 0.533 & 0.506 & 0.378 & 0.303 & 0.308 & 0.346 & 0.358 \\
\hline 9 & 0.865 & 0.701 & 0.580 & 0.497 & 0.444 & 0.477 & 0.471 \\
\hline $\mathrm{SCS}^{*}$ & \multicolumn{7}{|c|}{ Protein percentage } \\
\hline 0 & --- & --- & --- & --- & --- & --- & --- \\
\hline 1 & $0.080^{\mathrm{b}}$ & $0.019^{\text {ns }}$ & 0.017 & 0.014 & 0.012 & 0.027 & 0.039 \\
\hline 2 & 0.155 & 0.071 & 0.044 & 0.038 & 0.027 & 0.050 & 0.077 \\
\hline 3 & 0.186 & 0.109 & 0.074 & 0.064 & 0.056 & 0.074 & 0.102 \\
\hline 4 & 0.213 & 0.141 & 0.093 & 0.084 & 0.073 & 0.088 & 0.129 \\
\hline 5 & 0.236 & 0.164 & 0.108 & 0.099 & 0.091 & 0.109 & 0.146 \\
\hline 6 & 0.286 & 0.174 & 0.127 & 0.116 & 0.101 & 0.130 & 0.175 \\
\hline 7 & 0.330 & 0.201 & 0.157 & 0.141 & 0.129 & 0.152 & 0.198 \\
\hline 8 & 0.344 & 0.259 & 0.192 & 0.188 & 0.173 & 0.191 & 0.228 \\
\hline 9 & 0.512 & 0.393 & 0.308 & 0.314 & 0.310 & 0.319 & 0.354 \\
\hline
\end{tabular}

${ }^{*} 0: 0-17,000$ (cell/ml), 1: 18,000-34,000, 2: 35,000-70,000, 3: 71,000-140,000, 4: 141,000-282,000, 5: 283,000-565,000, 6: 566,000-1,130,000, 7: $1,131,000-2,262,000,8: 2,263,000-4,525,000,9: 4,526,000$-and above;

All the differences were significant at $p<0.0001$; ${ }^{\mathrm{a}, \mathrm{b}}$ : significant at $p<0.01, p<0.05$; ns: non-significant

higher percentages of T-cells in their colostrum compared to heifers. Several studies have demonstrated that the changes in milk composition caused by mastitis and high somatic cell count maybe explained by epithelial cell damage and increase in vascular permeability with the passage of immunoglobulins, serum protein and minerals and an increase in proteolytic activities (Le Roux et al., 2003; Cunha et al., 2008; Sharif and Muhammad, 2008). Generally, elevated somatic cell count is accompanied by changes in milk composition, which may result in decreased cheese yield, increased rennet clotting time, reduction of the shelf-life of pasteurized milk and modifications in thermal stability (Le Roux et al., 2003).

Effect of season of test-day on content and percentage of milk fat and protein is shown in Table 7. The highest and the lowest content and percentage of milk fat was in winter and summer, respectively. Also, the highest and the lowest content and percentage of milk protein was observed in fall and summer, respectively. Several investigation (Auldist et al., 1998; Sharma et al., 2002; Amenu et al., 2006; Malek dos Reis et al., 2013) reported significant effect of season on total content and composition of milk. Sharma et al. (2002) reported that milk fat percentage, cheese yield and total milk solids were highest from November to February and lowest from July to September. Contrary to the result of this study, Malek dos Reis et al. (2013) declared that milk fat and protein percentage of Gyr cows in Brazil were higher during the dry season (April to September). Probably, this is due to that Brazil is located in the southern hemisphere and average temperature during dry season is lower than rainy season (October to March). Different reasons were represented for the effect of season on milk composition. Hattem et al. (2012) attributed the decrease in milk solid content during summer to the high temperature and poorer quality pastures. Hegazi (2004) attributed the ef- 
Table 6: Regression coefficients of fat and protein percentage on SCS in primiparous and multiparous cows, based on test-day records, in different stages of lactation

\begin{tabular}{|c|c|c|c|c|c|c|}
\hline & \multicolumn{6}{|c|}{ Weeks of lactation } \\
\hline & $1-2$ & $3-8$ & $9-16$ & $17-24$ & $25-32$ & $33-44$ \\
\hline \multicolumn{7}{|l|}{ Fat percent } \\
\hline $1^{\text {st }}$ parity cows & 0.0744 & 0.0713 & 0.0588 & 0.0537 & 0.0495 & 0.0455 \\
\hline $2^{\text {nd }}$ parity cows & 0.0627 & 0.0521 & 0.0458 & 0.0456 & 0.0414 & 0.0481 \\
\hline$\geq 3^{\text {rd }}$ parity cows & 0.0557 & 0.0448 & 0.0383 & 0.0345 & 0.0386 & 0.0388 \\
\hline \multicolumn{7}{|l|}{ Protein percent } \\
\hline $1^{\text {st }}$ parity cows & 0.0399 & 0.0378 & 0.0341 & 0.0293 & 0.0292 & 0.0312 \\
\hline $2^{\text {nd }}$ parity cows & 0.0385 & 0.0304 & 0.0295 & 0.0290 & 0.0283 & 0.0320 \\
\hline$\geq 3^{\text {rd }}$ parity cows & 0.0385 & 0.0287 & 0.0287 & 0.0278 & 0.0286 & 0.0324 \\
\hline
\end{tabular}

All the differences were significant at $p<0.0001$.

Table 7: Effect of season on content and percentage of milk fat and protein based on test-day records

\begin{tabular}{lllll}
\hline Item & Spring & Summer & Fall & Winter \\
\hline Fat yield & $1.0594^{\mathrm{b}}$ & $0.9992^{\mathrm{d}}$ & $1.054^{\mathrm{c}}$ & $1.1173^{\mathrm{a}}$ \\
Fat \% & $3.1875^{\mathrm{c}}$ & $3.1163^{\mathrm{d}}$ & $3.2740^{\mathrm{b}}$ & $3.3695^{\mathrm{a}}$ \\
Protein yield & $1.0141^{\mathrm{c}}$ & $0.9678^{\mathrm{d}}$ & $1.0284^{\mathrm{b}}$ & $1.0547^{\mathrm{a}}$ \\
Protein \% & $3.0361^{\mathrm{c}}$ & $3.0063^{\mathrm{d}}$ & $3.1888^{\mathrm{a}}$ & $3.1662^{\mathrm{b}}$ \\
\hline
\end{tabular}

All the differences were significant at $p<0.0001$.

fect of the seasonal variations on milk composition to the type of feeding. However, Amenu et al. (2006) included two feeding systems in their study and concluded that differences between seasons can be largely attributed to the stage of lactation. These authors also declared that "although there were several significant differences in milk composition between seasons, only the protein and casein contents differed significantly between the feeding systems". Different reports can be due to difference in climates and accessibility to facilities and the kind of production systems. Nonetheless, considering that cows are fed manually throughout the year in Iran, increase in content and percentage of milk fat in winter can be attributed to decrease in temperature relative to the other seasons of the year that encourages the cows to consume more forage and fiber to produce heat.

\section{CONCLUSIONS}

The use of a relative large data set was the important attribute of the current study. In addition, the study was considering different range of independent variables. It has been shown that increase in SCS leads to increase in milk fat and protein percentage that is higher in early lactation relative to later parts of lactation. Also, the in- crease in milk fat and protein percentage due to increase in SCS is higher in lower lactations. Season of test-day had significant effect on content and percentage of milk fat and protein, and the highest production of milk fat and protein was observed during the winter and fall season. Considering these results, it seems necessity to include the effect of number of somatic cells on milk composition when calculating economic weights of somatic cell count and mastitis.

\section{ACKNOWLEDGEMENTS}

The authors are grateful to the Animal Breeding Center of Iran for providing the data for this study.

\section{REFERENCES}

Allen, M. S. (2000). Effects of diet on short-term regulation of feed intake by lactating dairy cattle. Journal of Dairy Science, 83, 1598-1624. https://doi.org/10.3168/jds.S00220302(00)75030-2

Amenu, B., Cowan, T., Deeth, H., \& Moss, R. (2006). Impacts of feeding system and season on milk composition and Cheddar cheese yield in a subtropical environment. Australian 
Journal of Experimental Agriculture, 46, 299-306. https:// doi.org/10.1071/EA04068

Atasever, S., \& Stádník, L. (2015). Factors affecting daily milk yield, fat and protein percentage, and somatic cell count in primiparous Holstein cows. Indian Journal of Animal Research, 49(3), 313-316. https://doi.org/10.5958/09760555.2015.00048.5

Auldist, M. J., Coats, S., Rogers, G. L., \& Mcdowell, G. H. (1995). Changes in the composition of milk from healthy and mastitic dairy cows during lactation cycle. Australian Journal of Experimental Agriculture, 35, 427-436. https:// doi.org/10.1071/EA9950427

Auldist, M. J., Walsh, B. J., \& Thomson. N. A. (1998). Seasonal and lactational influences on bovine milk composition in New Zealand. Journal of Dairy Research, 65(3), 401-411. https://doi.org/10.1017/S0022029998002970

Bansal, B. K., Hamann, J., Grabowski. N., \& Singh, K. B. (2005). Variation in the composition of selected milk fraction samples from healthy and mastitis quarters, and its significance for mastitis diagnosis. Journal of Dairy Research, 72, 144152. https://doi.org/10.1017/S0022029905000798

Barłowska, J., Litwińiczuk, Z., Wolanciuk, A., \& Brodziak, A. (2009). Relationship of somatic cell count to daily yield and technological usefulness of milk from different breeds of cows. Polish Journal of Veterinary Sciences, 12(1), 75-79.

Chegini, A. (2010). Genetic and environmental relationship among milk yield, persistency of milk yield, somatic cell count and calving interval of Holstein cows in Iran (Master's thesis). University of Guilan, Iran.

Cinar, M., Serbester, U., Ceyhan, A., \& Gorgulu, M. (2015). Effect of somatic cell count on milk yield and composition of first and second lactation dairy cows. Italian Journal of Animal Science, 14, 105-108. https://doi.org/10.4081/ ijas.2015.3646

Cunha, R. P. L., Molina, L. R., Carvalho, A. U., Facury Filho, E. J., Ferreira, P. M., \& Gentilini, M. B. (2008). Subclinical mastitis and relationship between somatic cell count with number of lactations, production and chemical composition of milk. Arquivo Brasileiro de Medicina Veterinária e Zootecnia, 60(1), 19-24. https://doi.org/10.1590/S010209352008000100003

Dobranié, V., Njari, B., Samardžija, M., Mioković, B., \& Resanović, R. (2008). The influence of the season on the chemical composition and the somatic cell count of bulk tank cow's milk. Veterinarski Arhiv, 78(3), 235-242.

Dohoo, L., Smith, R., Andersen, S., Kelton, D. F., \& Godden, S. (2011). Diagnosing intramammary infections: evaluation of definitions based on a single milk sample. Journal of Dairy Science, 94, 250-261. https://doi.org/10.3168/ jds.2010-3559

Dürr, J. W., Cue, R. I., Monardes, H. G., Moro-Méndez, J., \& Wade, K. M. (2008). Milk losses associated with somatic cell counts per breed, parity and stage of lactation in Canadian dairy cattle. Livestock Science, 117, 225-232. https:// doi.org/10.1016/j.livsci.2007.12.004

Forsbäck, L., Lindmark-Mansson, H., Andrén, A., \& Svennersten-Sjaunja, K. (2010). Evaluation of quality changes in udder quarter milk from cows with low-to-moderate somatic cell count. Animal, 4(4), 617-626. https://doi.org/10.1017/ S1751731109991467

Ghasemi, Z., Aslaminejad, A. A., Tahmoorespour, M., Rokuie, M., \& Faraji-Arugh, H. (2013). Estimates of genetic, environmental and phenotypic and correlations between production traits and somatic cell scores of Holstein cows of Iran. Animal science and research journal, 13, 37-50 [In Persian].

Hagnestam-Nielsen, C., Emanuelson, U., Berglund, B., \& Strandberg, E. (2009). Relationship between somatic cell count and milk yield in different stages of lactation. Journal of Dairy Science, 92, 3124-3133. https://doi.org/10.3168/ jds.2008-1719

Halasa, T., Huijps, K., Osteras, O., \& Hogeveen, H. (2007). Economic effects of bovine mastitis and mastitis management [a review]. Veterinary Quarterly, 29(1), 18-31. https://doi. org/10.1080/01652176.2007.9695224

Harmon, R. J. (1994). Physiology of mastitis and factors affecting somatic cell counts. Journal of Dairy Science, 77, 21032112. https://doi.org/10.3168/jds.S0022-0302(94)77153-8

Hattem, H. E., Taleb, A. T., Manal, A. N., \& Hanaa, S. S. (2012). Effect of pasteurization and season on milk composition and ripening of Ras cheese. Journal of Brewing and Distilling, 3(2), 15-22. https://doi.org/10.5897/JBD11.010

Hegazi, M. H. M. (2004). A study on the effect of some environmental conditions on chemical composition and some properties of milk (Doctoral dissertation). Tanta University, Egypt.

Hortet, P., Beaudeau, F., Seegers, H., \& Fourichon, C. (1999). Reduction in milk yield associated with somatic cell counts up to 600000 cells/ml in French Holstein cows without clinical mastitis. Livestock Production Science, 61, 33-42. https://doi.org/10.1016/ S0301-6226(99)00051-2

Kitchen, B. J. (1981). Review of the progress of dairy science: bovine mastitis: milk compositional changes and related diagnostic tests. Journal of Dairy Science, 48, 167-188.

Le Roux, Y., Laurent, F., \& Moussaoui, F. (2003). Polymorphonuclearproteolytic activity and milk composition change. Veterinary Research, 34, 629-645. https://doi.org/10.1051/vetres:2003021

Malek dos Reis, C. B., Barreiro, J. R., Mestieri, L., de Felício Porcionato, M, A., \& dos Santos, M. V. (2013). Effect of somatic cell count and mastitis pathogens on milk composition in Gyr cows. BMC Veterinary Research, 9, 67. https://doi.org/10.1186/1746-6148-9-67

Neitzel, A., Stamer, E., Junge, W., \& Thaller, G. (2015). Evaluation of different lactation curve models fitted for milk viscosity recorded by an automated on-line California mastitis test. Journal of Dairy Science, 82(2), 185-192. https://doi.org/10.1017/ S0022029915000035

Olde Riekerink, R. G. M., Barkema, H. W., \& Stryhn, H. (2007) The effect of season on somatic cell count and the incidence of clinical mastitis. Journal of Dairy 
Science, 90, 1704-1715. https://doi.org/10.3168/ jds.2006-567

Ohtsuka, H., Terasawa, S., Watanabe, C., Kohiruimaki, M., Mukai, M., Ando, T., ... Morris, S. (2010). Effect of parity on lymphocytes in peripheral blood and colostrum of healthy Holstein dairy cows. The Canadian Journal of Veterinary Research, 74, 130-135.

Østerås, O. (2000). The cost of mastitis - an opportunity to gain more money. In: Proceedings of the British mastitis conference (pp. 67-77). Shepton Mallet, U.K.

Pyörälä, S. (2003). Indicators of inflammation in the diagnosis of mastitis. Veterinary Research, 34(5), 565-578. https://doi.org/10.1051/vetres:2003026

Rajčevič, M., Potočnik, K., \& Levstek, J. (2003). Correlations between somatic cells count and milk composition with regard to the season. Agriculturae Conspectus Scientificus, 68(3), 221-226.

Rogers, S. A., Mitchell, G. E., \& Bartley, J. P. (1989). The relationship between somatic cell count, composition and manufacturing properties of bulk milk 4nonprotein constituents. Australian Journal of Dairy Technology, 44, 53-56.

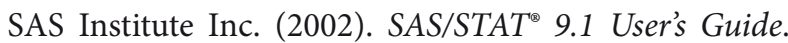
Cary, NC: SAS Institute Inc.

Schukken, Y. H., Wilson, D. J., Welcome, F., GarrisonTinofsky, L., \& Gonzales, R. N. (2003). Monitoring udder health and milk quality using somatic cell counts. Veterinary Research, 34, 579-596. https://doi. org/10.1051/vetres:2003028

Seegers, H., Fourichon, C., \& Beaudeau, F. (2003). Production effects related to mastitis and mastitis economics in dairy cattle herds. Veterinary Research, 24, 475-491. https://doi.org/10.1051/vetres:2003027

Sharif, A., \& Muhammad, G. (2008). Somatic cell count as an indicator of udder health status under modern dairy production [a review]. Pakistan Veterinary Journal, 28, 194-200.

Sharma, R. B., Kumar, M., \& Pathak, V. (2002). Effect of different seasons on cross-bred cow milk composition and paneer yield in sub-Himalayan region. Asian-Australian Journal of Animal Science, 15(4), 528-530. https://doi.org/10.5713/ajas.2002.528 